Research paper

\title{
The changing trend in songbirds' abundance, variety and physical condition in Connecticut's forestry habitat
}

\author{
Kelly Lawlor and Yunliang Meng*
}

Lawlor, K., Meng, Y. 2019. The changing trend in songbirds' abundance, variety and physical condition in Connecticut's forestry habitat. - Forestry Studies | Metsanduslikud Uurimused 70, 17-30, ISSN 1406-9954. Journal homepage: http:// mi.emu.ee/forestry.studies

\begin{abstract}
Songbirds are facing rapid population declines in Connecticut due to habitat loss. Man-made habitats such as powerline corridors are one of the few remaining ideal habitats for songbirds in the state. This study aims to determine if the abundance and variety of songbirds in four selected forests (i.e. Naugatuck State Forest, Sharon Audubon Society, Miles Wildlife Sanctuary, and Great Mountain Forest Species Variety) in Connecticut show patterns of decline from 2005 to 2014. This study also compares the physical condition of songbirds captured along a powerline corridor in the Naugatuck State Forest with those captured in the rest three non-fragmented forests in Northwestern Connecticut using Mann-Whitney U tests. Weight and wingspan are used as indicators of bird physical condition. The results demonstrate that the three non-fragmented forests experienced a steady decline in the variety of songbirds between 2005 and 2014. In addition, songbirds' abundance decreased steadily during the same period, except that of the ovenbird (Seiurus aurocapilla) and wood thrush (Hylocichla mustelina) in Miles Wildlife Sanctuary. The results from the Mann-Whitney U test have shown that after sex- and age-controlled features, the physical conditions of the three selective songbirds - veery (Catharus fuscescens), ovenbird, and wood thrush - tend to be better in the Naugatuck State Forest than in the three non-fragmented forests - Sharon Audubon Society, Miles Wildlife Sanctuary, and Great Mountain Forest Species Variety. Given are recommendations on how to protect the shrubland habitat along powerline corridors and how to create the shrubland habitat in non-fragmented forests.
\end{abstract}

Key words: birds, weight, wingspan, forest, temporal, USA.

Authors' addresses: Department of Geography, Central Connecticut State University, 1615 Stanley Street, CT 06050 New Britain, United States of America; *e-mail: mengy@ccsu.edu

\section{Introduction}

Birds can be found on every continent on earth and inhabit a wide range of habitats across the globe (Gill, 2007). They play a pivotal role in helping to sustain the overall health of the natural world (Lebbin et al., 2010). For example, birds are very ef- ficient at controlling pests in an ecosystem. More than $50 \%$ of all bird species eat only insects and this helps to control or lessen the effects of seasonal outbreaks of insects such as cicadas (Magicicada spp.) and crickets (Acheta spp.). Forest ecosystems are also directly benefited by birds that eat select species of beetles which destroy 
certain species of trees. For example, the American three-toed woodpecker (Picoides dorsalis) has been reported to eat the larvae of Spruce beetles (Dendroctonus rufipennis) in the Northwestern United States (Kelly et al., 2018; Fayt et al., 2005). Birds also aid in the pollination of plants and trees, and it is estimated that nearly $33 \%$ of bird species help disperse seeds by dropping consumed fruits and coniferous seeds (Wenny et al., 2011; Yoon, 1994). Birds even help other animals in the process of creating a nest or gathering food. For example, certain species of woodpeckers create nest cavities inside trees which are later used by other forest-dwelling mammals, rodents, and other species of birds (Gill, 2007).

Birds and their forest habitat have a symbiotic relationship: each depends on and contribute to each other's success for survival. If a forest habitat is healthy and productive, then it will allow for many species of birds in high abundances to thrive. Concurrently, if it is in decline then there will be fewer birds inhabiting it and the overall health of both the forest and the birds inside it will continue to decline (Wenny et al., 2011). Unfortunately, an alarming trend of steep declines in the abundance and variety of songbirds has been observed across New England's forests. For example, out of the approximately forty species of shrubland-dependent songbirds in New England, over twenty species have been declining at a rate of four to seven percent per year and the main reason behind the declines is habitat loss (King \& Schlossberg, 2014; Schlossberg \& King, 2007).

In Connecticut, the loss of natural early successional habitats has caused songbirds to become more reliant on man-made habitats for survival (King et al., 2009). Powerline corridors are one of the few remaining shrubland habitats available for shrubland birds in the state. However, little research has been conducted on the variety and abundance of songbirds inside Connecticut's forests. In addition, the overall physical condition of songbirds inhabiting shrublands in Connecticut has also not been studied in depth. This research aims to fill the research gap by providing more empirical evidence to explore the variety and abundance of songbirds inside the selected Connecticut's forests over time and compare the physical condition of songbirds inhabiting shrublands inside a powerline corridor in Connecticut with those inside three non-fragmented forests in Connecticut. In this study, weight and wingspan were used as indicators for quantifying the physical condition of songbirds, since low weight or short wingspan is a sign of lack of development and growth in adult birds (Clark, 1979). In addition, low weight can be an important indicator of bird physical condition, since low-weight birds may not have enough energy to be alert to fight off predators or even be fit enough to breed or reproduce (Gill, 2007).

This article is organized as follows. Section 2 provides a review of songbirds and their habitats. Following this, Section 3 presents the methodology outlining a description of the study area, variables used in this study, and the analysis method Mann-Whitney U test. In Sections 4 and 5, the results and discussion are presented. The final section presents concluding remarks.

\section{Literature Review}

Songbirds are also called passerines, and include any member of the suborder Passeri or Oscines, of the order Passeriformes. All songbirds have a highly developed vocal system. Some songbirds such as thrushes (Hylocichla spp.) and warblers (Vermivo$r a$ and Setophaga spp.) are known for their beautiful calls; while others like crows have a harsh call. Nearly half of the birds in the world, about 4,000 species, are types of songbirds. Songbirds consume great quantities of pest insects and weed seeds each year. Songbirds eat seeds, berries, nectar, 
fruit, and insects. They benefit farmers and foresters by consuming millions of insects that could damage crops and trees (Wenny et al., 2011). Millions of homeowners and gardeners also appreciate this benefit. Certain species of songbirds depend on early successional forest habitats during breeding and post-fledgling periods. Abandoned farms, powerline corridors, and forest openings such as clear-cuts, are types of early successional habitats used by songbirds during these periods (Marshall et al., 2003; Vitz \& Rodewald, 2006).

Lands predominately covered by short woody plants, shrubs and bushes are known as shrubland habitats (McKnight \& Hess, 2008). Shrublands and young forests are often referred to as early successional habitats (Covell, 2006). Both natural events and manmade practices can create shrubland habitats. A natural event such as a wildfire, hurricane, or ice storm, can clear large portions of forested land in a short period of time. An alternative way to create early successional lands is to mechanically clear forest patches and continuously maintain them over time. Natural types of shrubland habitats in New England are mostly likely in the forms of beaver (Castor sp.) ponds, pitch pine (Pinus rigida Mill.)scrub oak (Quercus berberidifolia Liebm.) forest, treefall and blowdown areas, and wetlands.

Shrublands are critical wildlife habitats in that they are essential for the survival of songbirds. In the Northeastern United States, there are about 41 songbird species that rely exclusively on shrublands for habitat and reproduction (Schlossberg \& King, 2007). The birds breeding inside shrublands and early successional forest habitats make up about $15 \%$ of the 231 bird species in the Northeast region (Sibley, 2000). However, in eastern North America, over the last 60 years, open habitats (grasslands, savannah, barrens, and shrublands) have declined by $98 \%$, with shrubland communities comprising $24 \%$ of this decline (Tefft, 2006). The loss of these habitats through conversion to other land uses, residential development or through succession is resulting in the decline and disappearance of songbirds dependent on early successional habitats. These habitat changes provide significant challenges for wildlife biologists who strive to protect songbirds and their habitats on the landscape.

Power utilities have pioneered the use of selective clearing and herbicide application to maintain stable shrub communities that will not interfere with power lines (Northeast Utilities, 2015). Relatively stable shrub communities can be created and maintained by eliminating trees with selective cutting, followed by selective herbicide application. Dense shrub clones can actually discourage invasion by trees for 15 years or more and result in stable shrublands once they have become established (Tefft, 2006). In New England, powerline corridors are an important shrubland habitat for songbirds because they provide a nesting habitat for species facing large declines in the Northeast United States (Askins, 1994; Dettmers, 2003; Confer \& Pascoe, 2003). When compared to clear-cut early successional growth sites, powerline right-of-ways exhibited similar levels of species richness and avian survivorship (Bulluck \& Buehler, 2006; King et al., 2001; Krementz \& Christie, 2000; Geibert, 1980). In 1953, a powerline corridor was established in the Connecticut College Arboretum. In 1993, the same corridor supported shrubland species such as white-eyed vireos (Vireo griseus), blue-winged warblers (Vermivora cyanoptera), chestnut-sided warblers (Setophaga pensylvanica), prairie warblers (Setophaga discolor), and field sparrows (Spizella pusilla) (Askins, 2002). Another powerline corridor in Montville, Connecticut also provided a habitat for songbirds that are of concern conservation (Askins et al., 2012). The State of Connecticut Department of Energy and Environmental Protection (CT DEEP) wildlife division biologists determined that shrubland habitats inside CT DEEP managed 
lands combined with all of the powerline corridors in the state can support roughly 1,700 blue-winged warblers, 2,700 eastern towhees (Pipilo erythrophthalmus), 550 field sparrows, and 1,200 prairie warblers (Huang, 2013). These numbers can boost the listed songbird population for about $10 \%$ to $20 \%$ according to the CT DEEP wildlife division staff (Huang, 2013).

\section{Materials and Methods}

\section{Study area - the Naugatuck State Forest and three non-fragmented forests}

Four study sites - Naugatuck State Forest, Miles Wildlife Sanctuary, Great Mountain Forest, and Sharon Audubon Society are located in the State of Connecticut, which is in the Northeastern region of the United States (Figure 1). The state is bordered by Massachusetts to the north, Rhode Island to the east and New York to the west. Although Connecticut is the third smallest state by area, it has 994.5 kilometers $(\mathrm{km})$ of coastline along Long Island Sound (NOAA, 1975). According to the US Census in 2018, Connecticut had a population of roughly 3.5 million. The population is centered along the central and southwest regions of the state (U.S. Census Bureau, 2019).

In 1921, Harris Whittemore, a Naugatuck area industrialist and member of the State Forest and Parks Commission purchased land for the Naugatuck State Forest (Figure 2a). After his death the land was donated to the State of Connecticut to be made into a State Forest. In December
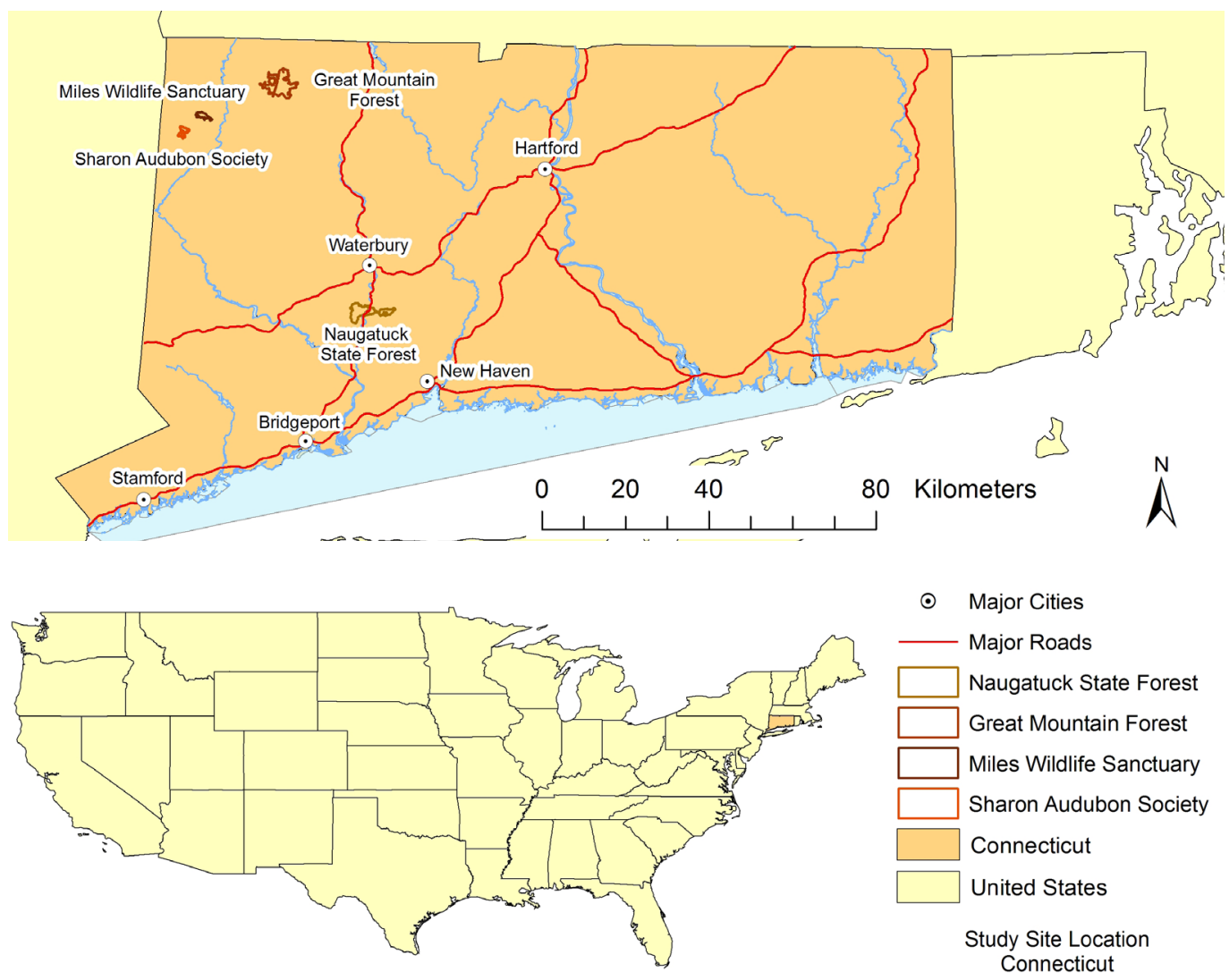

○ Major Cities

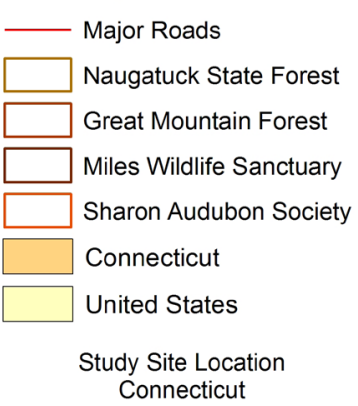

Figure 1. Connecticut's location in the U.S. 


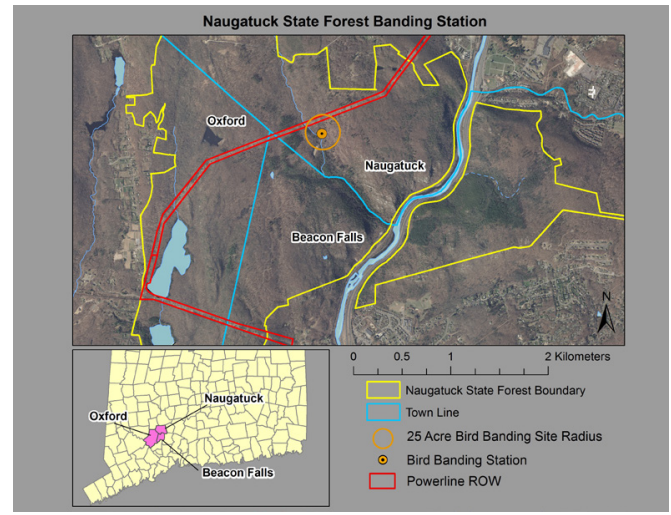

a. Naugatuck State Forest and banding station

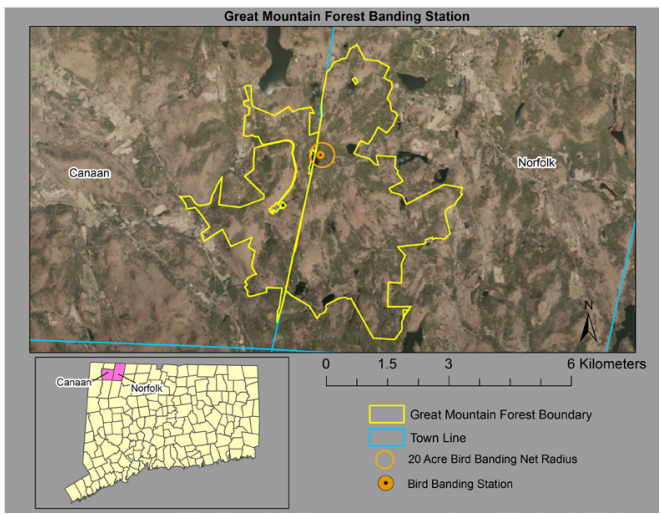

c. Great Mountain Forest and banding station

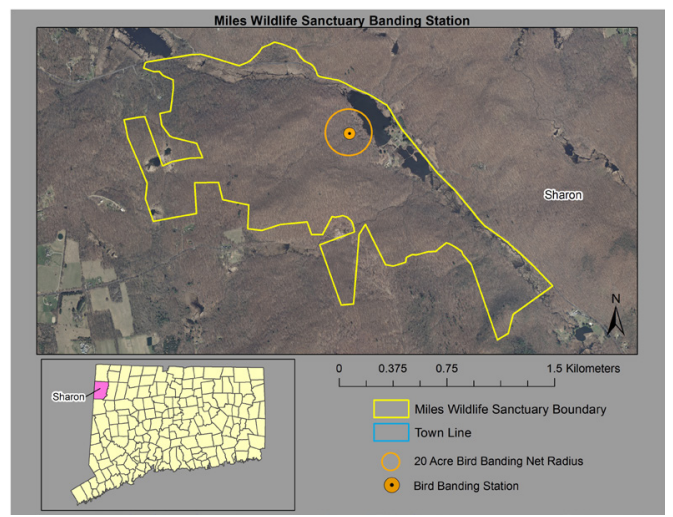

b. Miles Wildlife Sanctuary and banding station

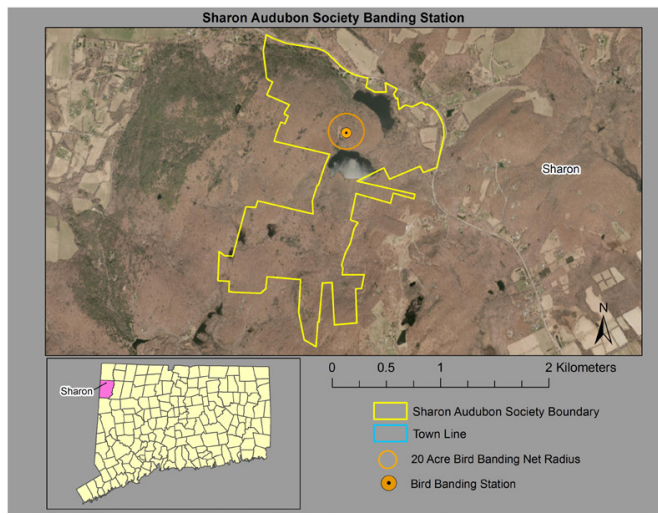

d. Sharon Audubon Society and banding station

Figure 2. Study area and banding station locations.

2004, Audubon Connecticut recognized 1390.5 hectares (ha) of the Naugatuck State Forest as an Important Birding Area (IBA). The area was recognized because it contains a wide variety of forest ecosystem habitats, such as wetlands, hemlock groves, shrubland and early successional forests, and areas of non-fragmented oldgrowth forests. The Naugatuck State Forest IBA is maintained by the CT DEEP forestry division (Devine, 2012).

There are two connected powerline corridors inside the west block of the State Forest and they account for 17.4 ha of the grassland and shrubland habitat. One corridor, known as the Naugatuck Tap, is 3.9 $\mathrm{km}$ in length, and has an average width of 39.6 meters $(\mathrm{m})$; the second corridor, known as the Beacon Falls Tap, is $1.6 \mathrm{~km}$ long and has an average width of $45.7 \mathrm{~m}$ (Devine, 2012). These particular power lines fragmenting the forested area are known as transmission lines because they supply electricity from a generating plant to a substation. Not only do these power lines supply the citizens of neighboring towns with electricity, they also provide a shrubland habitat for songbirds inside the forest.

A bird-banding station was only operated inside the Naugatuck State Forest in the summer seasons of 2008 and 2009 (Liefert, 2008). CT DEEP employees conducted the research in accordance with the Monitoring Avian Productivity and Survivorship (MAPS) program. The MAPS pro- 
gram was started in 1989 by the Institute for Bird Populations (IBP) (DeSante et al., 2014). The main objectives of the program are to assess bird populations and survival rates at each site. The location of the banding stations inside each of the study areas was chosen by determining where the most birds would be found within an area of 8.1 ha. Inside the area, 12 mist nets were set up to capture birds frequenting the surrounding habitat (DeSante et al., 2014). The Naugatuck State Forest banding station is shown in Figure 2a. In addition to the Naugatuck State Forest, three birdbanding sites were established in Northwestern Connecticut, Miles Wildlife Sanctuary in Sharon, Great Mountain Forest in Norfolk, and Sharon Audubon Society in Sharon, and are shown in Figures 2b, 2c, and $2 \mathrm{~d}$. The Miles Wildlife Sanctuary manages 607.0 ha of habitat amidst 2023.4 ha of protected forest in Sharon, CT. In addition to the forestland, the Miles Wildlife Sanctuary features $3.2 \mathrm{~km}$ of wetlands along Carse Brook, which supports a wide variety of flora and fauna, some of which are on the Connecticut's Endangered Species List. The Great Mountain Forest encompasses more than 2428.1 ha of contiguous forestland in the towns of Norfolk and Canaan, Connecticut. The Great Mountain Forest is also part of an ecologically vital corridor which helps form a bridge for wildlife and migratory songbirds in the northeast. The Sharon Audubon Society consists of 464.2 ha of mostly forest and includes $17.7 \mathrm{~km}$ of trails and two ponds. Inside the Sharon Audubon Society, there is a wildlife rehabilitation clinic for injured and orphaned wildlife. All of the three sites are non-fragmented old-growth forest habitats and the bird-banding data available in these sites is from 2005 to 2014.

\section{Bird sample data}

In order to determine the variety and abundance of species, and the physical condition of select species inside the Nau- gatuck State Forest, Miles Wildlife Sanctuary, Great Mountain Forest and Sharon Audubon Society, bird-banding data from the MAPS banding operations inside the study areas were used. In a bird-banding operation, the birds are captured using a mist net as shown in Figure 3. The net is made of thin nylon and is undetectable by birds. When birds fly into the net, they are caught in the hanging pockets and retrieved by trained bird banders. After they are removed from the net, they are banded with an aluminum or colored band, as shown in Figure 3. Then, information, such as the bird type, age, sex, weight, and wingspan, was gathered before each bird was released.

For songbirds, the Naugatuck State Forest banding station is located within a more ideal habitat, a fragmented forest with a large area of shrubland. The banding sites in the Miles Wildlife Sanctuary in Sharon, Great Mountain Forest in Norfolk, and Sharon Audubon Society in Sharon are located in a less than ideal habitat, a nonfragmented old-growth forest for songbirds. For the three study sites, the changing trend in the songbird abundance and variety was later analyzed and the physical condition of three types of songbirds banded in the three sites was compared with those banded in the Naugatuck State Forest. In this study, four species, ovenbird (Seiurus aurocapilla), red-eyed vireo (Vireo olivaceus), veery (Catharus fuscescens) and wood thrush (Hylocichla mustelina) were chosen because they are the common songbirds found in Connecticut during the breeding months and they are listed in the wildlife action plan as a target priority for conservation (Terwilliger Consulting Inc., 2015). The species veery and wood thrush are both members of the Turdidae family. They are both considered to be true thrushes and have very similar body weights and wingspans (Heckscher et al., 2017; Evans et al., 2011). They also share the same diet and live in the same habitat. The ovenbird is also similar to wood thrush and veery 

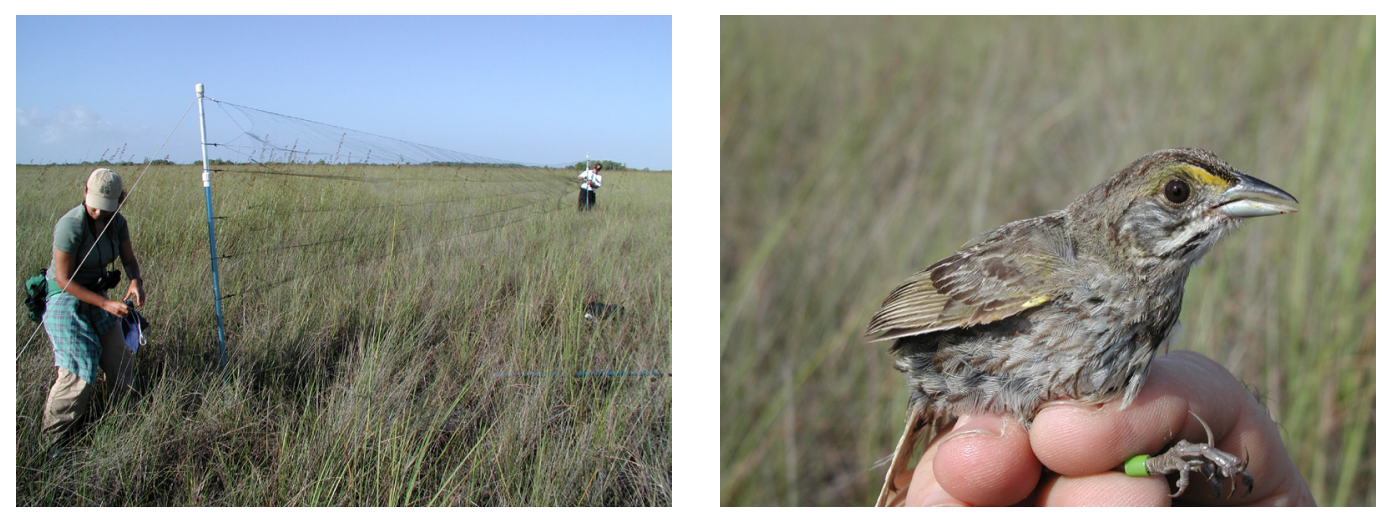

Figure 3. Mist net being set up and bird banding (Everglades National Park, 2002).

and all three species rely on the shrubland habitats in the powerline corridor for food during their breeding and nesting period. The sample sizes of each species inside the Naugatuck State forest during 2008 and
2009 and inside the three non-fragmented old-forest sites from 2005 to 2014 are shown in Table 1.

Table 1. Sample sizes for each species.

\begin{tabular}{lcccccc}
\hline & $\begin{array}{c}\text { Ovenbird } \\
\text { male }\end{array}$ & $\begin{array}{c}\text { Ovenbird } \\
\text { female }\end{array}$ & $\begin{array}{c}\text { Veery } \\
\text { male }\end{array}$ & $\begin{array}{c}\text { Veery } \\
\text { female }\end{array}$ & $\begin{array}{c}\text { Wood } \\
\text { Thrush male }\end{array}$ & $\begin{array}{c}\text { Wood Thrush } \\
\text { female }\end{array}$ \\
\hline $\begin{array}{l}\text { Naugatuck State Forest } \\
\begin{array}{l}\text { 2008-2009 } \\
\text { Non-powerline sites }\end{array}\end{array}$ & 18 & 4 & 14 & 4 & 13 & 5 \\
$2005-2014$ & 97 & 51 & 121 & 92 & 55 & 33 \\
\hline
\end{tabular}

\section{Statistical analysis}

For the analysis of the impact of shrubland habitats on songbirds' physical condition, the Mann-Whitney U test (Mann and Whitney, 1947; Hollander \& Wolfe, 1999) at a 0.05 significance level was conducted by using the Statistical Package for the Social Sciences (SPSS) to compare the means of adult songbirds' weight and wingspan (controlled by sex) regarding their banding locations. This non-parametric test was used as an appropriate tool because the bird-banding location data are defined as binary data and the distributions of the bird weight and wingspan do not follow the normal distributions.

\section{Results}

\section{The abundance of songbirds}

The abundance of veery, ovenbird, and red-eyed vireo inside the Miles Wildlife Sanctuary, Great Mountain Forest, and Sharon Audubon Society from 2005 to 2014 is shown in Figures 4-6 as below. A trend line is included in each figure to show the trend of abundance over time. As shown in the figures, for ovenbird, a slight decline in abundance was evident in the Great Mountain Forest and Sharon Audubon Society, and a slight increase in abundance occurred in the Miles Wildlife Sanctuary. For veery, the Sharon Audubon Society and Miles Wildlife Sanctuary showed a 
A. Great Mountain Forest

$$
y=-0.3818 x+7.4
$$
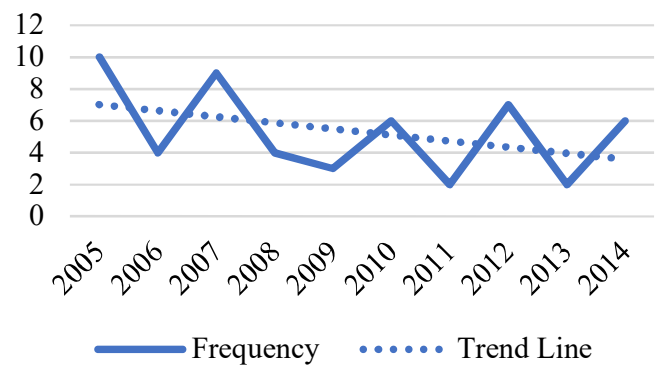

B. Sharon Audubon Society

$$
y=-0.103 x+14.667
$$

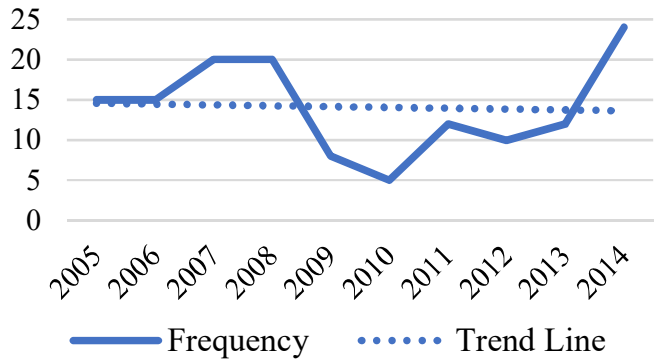

C. Miles Wildlife Sanctuary

$$
y=-0.1697 x+9.5333
$$

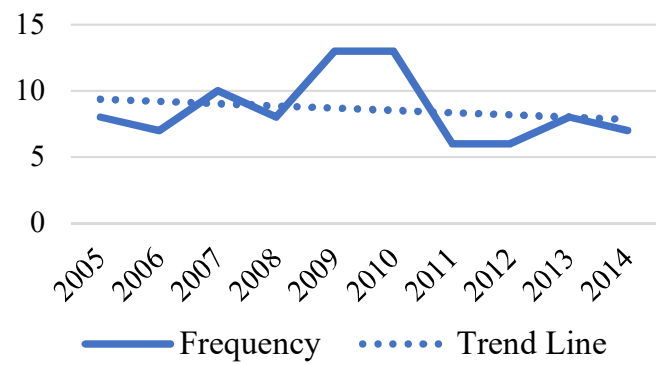

Figure 4. Veery abundance.

slight decline in species abundance and the Great Mountain Forest showed a noticeable decline in abundance. Red-eyed vireo experienced a slight decline inside the Great Mountain Forest, a very steep decline inside the Sharon Audubon Society, and a slight increase occurred inside the Miles Wildlife Sanctuary.
A. Great Mountain Forest

$y=-0.0485 x+8.2667$

15

10

5

0

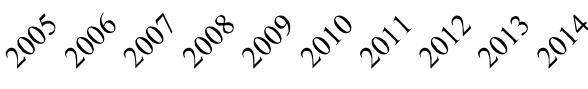

Frequency $\quad \ldots .$. Trend Line

B. Sharon Audubon Society

$y=-0.2788 x+11.933$

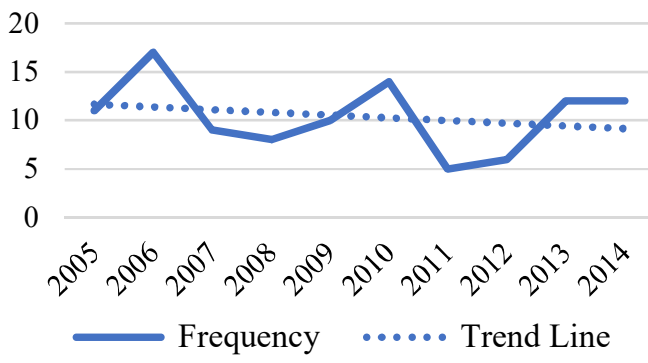

C. Miles Wildlife Sanctuary

$y=0.1152 x+5.0667$

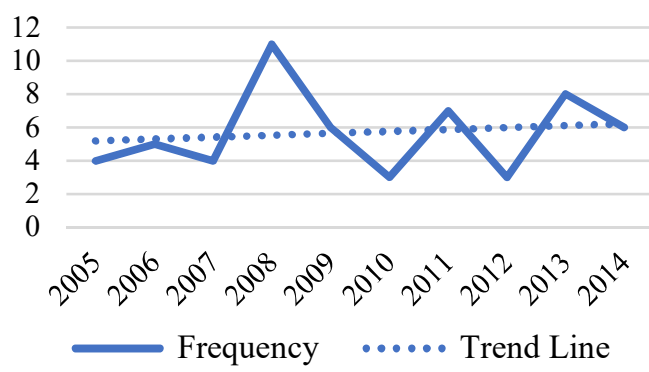

Figure 5. Ovenbird abundance.

\section{The variety of songbirds}

The number of the variety of species caught inside the Miles Wildlife Sanctuary, Sharon Audubon Society, and Great Mountain Forest in 2005-2014 are shown in Figures 7-9. A trend line is added in each figure to show the overall pattern of species variety over time in each site. The Miles Wildlife 


\section{A. Great Mountain Forest}

$$
y=-0.103 x+4.2667
$$

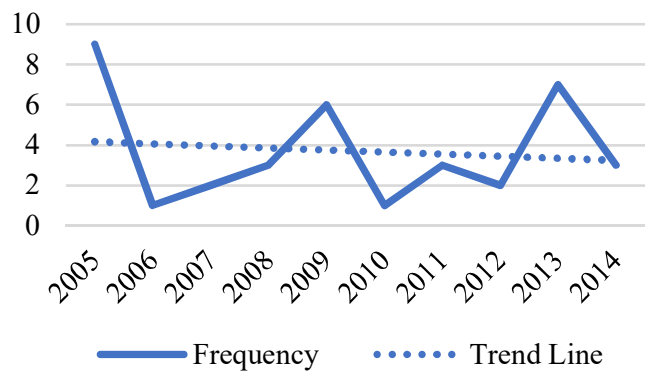

\section{B. Sharon Audubon Society}

$$
y=-1.9167 x+19.917
$$

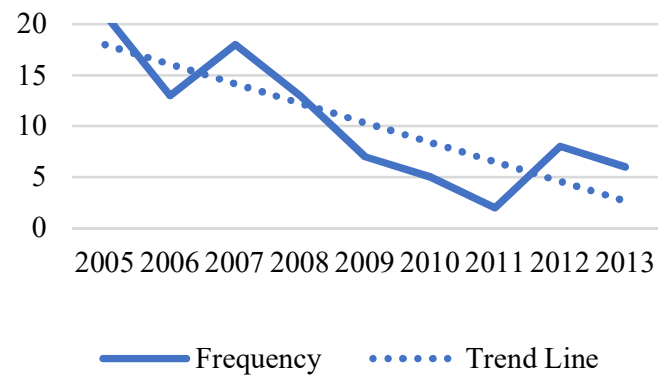

C. Miles Wildlife Sanctuary

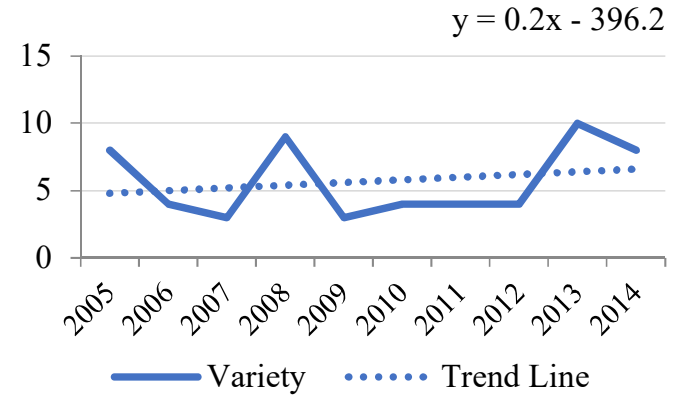

Figure 6. Red-eyed vireo abundance.

Sanctuary and Sharon Audubon Society experienced steep declines in species variety from 2005 to 2014. The Great Mountain Forest had a pattern of a slight decline change in the number of species found inside the station in 2005-2014.

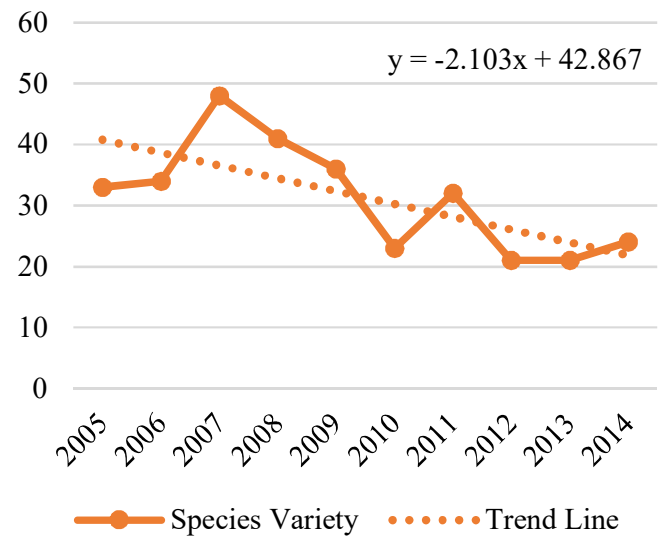

Figure 7. Species variety in Sharon Audubon Society.

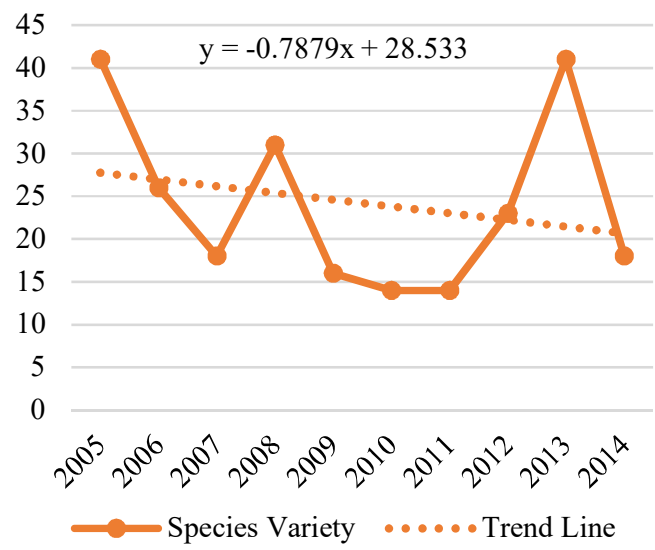

Figure 8. Species variety in Miles Wildlife Sanctuary.

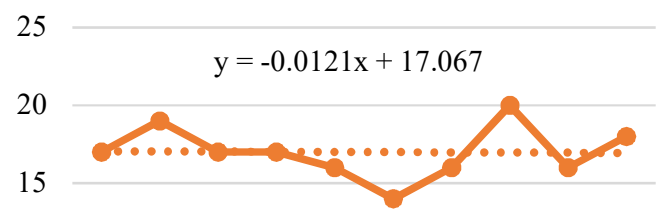

10

5

0

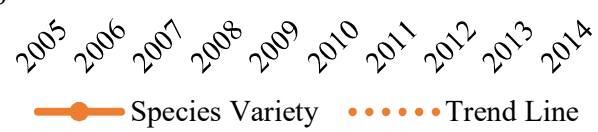

Figure 9. Species variety in Great Mountain Forest. 


\section{Mann-Whitney $U$ test results}

The outputs from the Mann-Whitney U test are demonstrated in Table 2, comparing the mean ranks of bird weight and wingspan for three types of songbirds: veery, ovenbird, and wood thrush. The mean rank for wingspan of adult male veeries was higher in the Naugatuck State Forest than the three non-fragmented forests and the difference was statistically significant $(p<0.05)$. The result indicates that adult male veeries tend to have a longer wingspan in the Naugatuck State Forest. The mean ranks for wingspan of adult female veeries, adult male and female ovenbirds, and adult male and female wood thrushes were higher in the Naugatuck State Forest compared to the three non-fragmented forests. The results indicate that these birds tend to have a longer wingspan in the
Naugatuck State Forest than those living in the three non-fragmented forests, but the wingspan differences are not statistically significant $(p>0.05)$. For adult male and female veeries, adult female ovenbirds, and adult male wood thrushes, the mean ranks for weight in the Naugatuck State Forest were higher than in the three non-fragmented forests. The results indicate that the birds living in the Naugatuck State Forest tend to have higher weight than those living in the three non-fragmented forests, but these differences are not statistically significant $(p>0.05)$. For adult male ovenbirds and adult female wood thrushes, the mean ranks in the three non-fragmented forests were higher, but the difference was also statistically insignificant.

Table 2. Mann-Whitney U test weight and wingspan mean ranks. NSF - Naugatuck State Forest.

\begin{tabular}{lcccc}
\hline & $\begin{array}{c}\text { Mean rank } \\
\text { weight }\end{array}$ & $\begin{array}{c}\text { Mean rank } \\
\text { weight }\end{array}$ & $\begin{array}{c}\text { Mean rank } \\
\text { wingspan }\end{array}$ & $\begin{array}{c}\text { Mean rank } \\
\text { wingspan }\end{array}$ \\
\cline { 2 - 5 } & NSF & 0ther & NSF & 0ther \\
\hline Adult male veery* & 22.00 & 15.33 & $26.36^{*}$ & 12.43 \\
Adult female veery & 17.25 & 10.89 & 14.50 & 11.47 \\
Adult male ovenbird & 18.44 & 19.53 & 21.61 & 16.53 \\
Adult female ovenbird & 10.88 & 6.95 & 9.00 & 7.64 \\
Adult male wood thrush & 22.69 & 19.56 & 23.35 & 18.50 \\
Adult female wood thrush & 5.40 & 5.60 & 7.50 & 6.50 \\
\hline
\end{tabular}

$* p<0.05$

\section{Discussion and Recommendations}

Inside the three non-fragmented forest sites, the variety of bird species decreased steadily over time between 2005 and 2014. In addition, the selected songbirds' abundance also decreased steadily during the same period, except that of the ovenbird and wood thrush in the Miles Wildlife Sanctuary. The results from the MannWhitney U test have shown that after sexand age-controlled features, three selective songbirds - veery, ovenbird, and wood thrush - tend to have a longer wingspan inside the Naugatuck State Forest rather than in the three non-fragmented forest sites - Sharon Audubon Society, Miles Wildlife Sanctuary, and Great Mountain Forest Species Variety. In addition, adult male and female veeries, adult female ovenbirds, and adult male wood thrushes tend to have higher weight inside the Naugatuck State Forest rather than in the three non-fragmented forest sites. Considering the results, the following recommendations are given to better manage existing shrubland habitats or establish new shrubland habitats in Connecticut. 
Managing the shrubland habitat in powerline corridors

Eversource Energy, formerly known as Northeast Utilities, is the utility company in charge of controlling the vegetation in the powerline corridors of the Naugatuck State Forest. The maintenance takes place every four years and both mechanical and chemical management practices are used (Northeast Utilities, 2015). Herbicides should not be sprayed inside the powerline corridors from April to August, since adult songbirds begin to build nests and care for hatchlings during this time. If herbicide treatments are applied to an active habitat (i.e. a powerline corridor), significantly reduced is the amount of insects needed to feed newly hatched young and adult birds inside the corridor (Taylor et al., 2006). The chemical treatments can be used outside of the summer season in order to control invasive plant species and promote native vegetation growth. In the powerline corridors in the Naugatuck State Forest, mechanical removal of undesired trees and vegetation is conducted and completed in the winter months after songbirds have migrated south. This process of mechanical vegetation removal should be repeated in the future. Linking existing and planned clear-cuts in close proximity to the powerline corridors can expand the total area of the shrubland habitat. However, this should only be a suitable option after figuring out how far the powerline corridor was from the clear-cut land while also considering the amount of old-growth forest that would have to be cut down to connect the two areas together. A long-term plan should be created which would minimize the amount of old-growth forest habitat lost, while still creating and establishing a connection to the shrubland habitat inside the powerline corridor.

A persistent problem inside the powerline corridors in the Naugatuck State Forest is all-terrain vehicles and dirt bikes. Such human activities can damage the songbirds' habitat and degrade the poten- tial usability of the shrubland habitat in the powerline corridors. The Naugatuck State Forest is a large area to patrol for unwanted all-terrain vehicles and dirt bikes but, patrols inside the powerline corridors during important nesting periods for shrubland birds can help reduce habitat loss and nest disturbances that could lead to nest abandonment. More signs stating that the area is a high-priority habitat should be posted in the powerline corridors during the summer months to discourage people from riding all-terrain vehicles or dirt bikes in the area.

\section{Creating the shrubland habitat}

It is estimated that there are 50,835 ha of early succession land in Connecticut. $78 \%$ of the early successional habitat throughout New England is in the form of re-generating clearcuts following timber harvests. The remaining percentage is a combination of pitch pine-scrub oak, wetlands and power line and utility right of ways (Schlossberg \& King, 2007). Currently, powerline corridors comprise only $2.1 \%$ of the shrubland habitat in southern New England (King et al., 2009). The most common forest type in Connecticut is oak/hickory, which represent $71 \%$ of Connecticut's forest land (Butler, 2016). The vast majority, around $75 \%$ of these forested lands is privately owned (Butler et al., 2011). The landownership requires the Connecticut governments to collaborate with private landowners to provide a large area of early successional habitat for protecting songbirds on their properties. According to the 2015 Connecticut Wildlife Action Plan (WAP), the DEEP wildlife department has set a goal to have 9712.4 ha of the shrubland habitat in Connecticut by 2025. Selectively thinning the old forest can be used to create gaps and keep trees that produce fruits, nuts, seeds, and acorns which can be utilized by songbirds and other forest-dwelling animals. Dead or decaying trees should be preserved because they provide nesting opportunities and food resources for songbirds and other forest wildlife (Rodewald, 2001). Selective thinning will also let songbirds 
utilize the young forest habitat during the next breeding season. Clear-cutting the land can be another option if the intention is to revert the area back to a beginning stage in forest succession but is very disruptive to the existing and surrounding habitat. After an area is completely cleared of vegetation, it will start to regenerate on its own and will be able to sustain songbirds after a few years of growth. Clear-cutting a larger area will create a new habitat for songbirds over time, but the current wildlife living inside the forested area will be displaced. Consequently, clear-cutting should be an option only after DEEP has evaluated and approved the plan.

One alternative option can be to identify property on an abandoned farm or an old field, which will progress through forest succession naturally over time. The succession process in an old field can be jumpstarted by planting native shrubs and saplings. Native vegetation is easier to maintain than invasive species and provides food and shelter for songbirds in the spring and summer months. Native bushes and shrubs also provide an excellent nesting and shelter cover for songbirds that live in Connecticut all year round or during the winter. Planting a large variety of different native shrubs, and low-lying vegetation will help restore a high diversity of songbird species by catering to the different needs of selective songbirds, which have distinct shelter and food preferences.

Regardless of the method used, the wild life department will need to evaluate if the proposed land is a beneficial addition to the population goals set by the 2015 WAP. The wildlife department should monitor new shrublands created so that the total number of acres does not surpass its target goal, because although creating the shrubland habitat for songbirds facing declines is important, exceeding the target acreage for shrublands could potentially cause a population decline from habitat loss for birds that rely on old-growth forests.

\section{Conclusions}

The three non-fragmented forest sites; Sharon Audubon Society, Miles Wildlife Sanctuary, and Great Mountain Forest Species Variety, have shown a steady decline in the variety of bird species and in the abundance of selected songbirds between 2005 and 2014. In addition, songbirds' abundance decreased steadily during the same period, except that of the ovenbird and wood thrush in the Miles Wildlife Sanctuary. The results from the Mann-Whitney U test have shown that after sex- and agecontrolled features, the physical conditions of the three selective songbirds - veery, ovenbird, and wood thrush - tend to be better in the Naugatuck State Forest than in the three non-fragmented forests - Sharon Audubon Society, Miles Wildlife Sanctuary, and Great Mountain Forest Species Variety.

The 2015 WAP created for the CT DEEP states that the main threat to songbirds is habitat loss, which is why it is very important to conserve the remaining powerline corridor areas. Given the limited amount of early successional lands in Connecticut, this study gave recommendations on how to better manage early successional forests along powerline corridors in the Naugatuck State Forest. The current shrubland habitat inside powerline corridors in Connecticut is not large enough to support high populations of many shrubland species facing declines. In addition, this study calls for the creation of new shrublands on private lands in Connecticut in order to provide the shrubland habitat for songbirds facing a steady decline.

This study is not without limitations. The primary limitation is the data availability. Only a limited number of years' bird data are available and the data were only collected in four bird-banding stations in Connecticut. In fact, the Naugatuck State Forest only operated a MAPS banding station inside the powerline corridor for two consecutive years in 2008 and 2009. If all 
bird data were available in the Naugatuck State Forest from 2005 to 2014, MannWhitney $\mathrm{U}$ tests could be conducted again and a statistically significant difference in weight and wingspan might be detected for all three selected songbirds which live in the Naugatuck State Forest and in the three non-fragmented forests. In addition, it should be noted that the results and discussion are all based on the analysis of bird data collected between 2005 and 2014; the change of available data might change the results and indications significantly.

\section{References}

Askins, R.A. 1994. Open corridors in a heavily forested landscape: Impact on shrubland and forest-interior birds. - Wildlife Society Bulletin, 22(2), 339-347.

Askins, R.A. 2002. Restoring North America's Birds: Lessons from Landscape Ecology. New Haven, Yale University Press. 352 pp.

Askins, R.A., Folsom-O'Keefe, C.M., Hardy, M.C. 2012. Effects of vegetation, corridor width and regional land use on early successional birds on powerline corridors. - PloS One, 7(2), e31520.

Bulluck, L.P., Buehler, D.A. 2006. Avian use of early successional habitats: Are regenerating forests, utility right-of-ways and reclaimed surface mines the same? - Forest Ecology and Management, 236(1), 76-84.

Butler, B.J. 2016. Forests of Connecticut, 2015. Resource Update FS-83. Newtown Square, PA: U.S. Department of Agriculture, Forest Service, Northern Research Station. 4 p.

Butler, B.J., Barnett, C.J., Crocker, S.J., Domke, G.M., Gormanson, D., Hill, W.N., Kurtz, C.M., Lister, T., Martin, C., Miles, P.D., Morin, R., Moser, W.K., Nelson, M.D., O'Connell, B., Payton, B., Perry, C.H., Piva, R.J., Riemann, R., Woodall, C.W. 2011. The Forests of Southern New England, 2007: A report on the forest resources of Connecticut, Massachusetts, and Rhode Island. Newtown Square, Pennsylvania: U.S. Dept. of Agriculture, Forest Service, Northern Research Station. 48p.

Clark, G.A. Jr. 1979. Body weights of birds: A review. - The Condor, 81, 193-202.

Confer, J.L., Pascoe, S.M. 2003. Avian communities on utility rights-of-ways and other managed shrublands in the northeastern United States. - Forest Ecology and Management, 185(1-2), 193-205.
Covell, D. 2006. Introduction. - Oehler, J.D. Covell, D.F., Capel, S., Long, B. (eds.). Managing Grasslands, Shrublands, and Young Forest Habitats for Wildlife: A Guide for the Northeast. Westboro, MA, The Northeast Upland Technical Committee and Massachusetts Division of Wildlife and Fisheries, 1-6.

DeSante, D.F., Burton, K.M., Velez, P., Froehlich, D., Kaschube, D.R. 2014. Instructions for the establishment and operation of constant-effort bird-banding stations as part of the monitoring avian productivity and survivorship (MAPS) program. - MAPS manual. Point Reyes Station, California, The Institute for Bird Populations. 43 pp.

Dettmers, R. 2003. Status and conservation of shrubland birds in the northeastern US. Forest Ecology and Management, 185(1-2), 81-93.

Devine, B. 2012. Important Bird Area Conservation Plan: Naugatuck State Forest. - Conservation plan. Plymouth, CT, Audubon Connecticut. $160 \mathrm{pp}$.

Evans, M., Gow, E., Roth, R.R., Johnson, M.S., Underwood, T.J. 2011. Wood Thrush (Hylocichla mustelina). The Birds of North America Online - Poole, A. (ed.). Ithaca, NY, Cornell Lab of Ornithology; Retrieved from the Birds of North America. [WWW document]. - URL http://0-bna.birds.cornell.edu.www. consuls.org/bna/species/246. [Accessed 1 October 2019].

Everglades National Park. 2002. Seaside Sparrow Banding Research. Digital image. [WWW document]. - URL https://www.flickr.com/ photos / evergladesnps / 9250338006/in / album-72157634251224116/. [Accessed 28 August 2019].

Fayt, P., Machmer, M.M., Steeger, C. 2005. Regulation of spruce bark beetles by woodpeckers - a literature review. - Forest Ecology and Management, 206(1-3), 1-14.

Geibert, E.H. 1980. Songbird diversity along an urban power line right-of-way in Rhode Island. - Environmental Management, 4(3), 205-213.

Gill, F.B. 2007. Ornithology. 3rd Edition. New York, W.H. Freeman and Company. 758 pp.

Heckscher, C.M., Bevier, L.R., Poole, A.F., Moskoff, W., Pyle, P., Patten, M.A. 2017. Veery (Catharus fuscescens). - Rodewald, P. (ed.). The Birds of North America. Ithaca, NY Cornell Lab of Ornithology. Retrieved from the Birds of North America. [WWW document]. - URL https:/ / doi-org.ccsu.idm.oclc.org/10.2173/ bna.veery.03. [Accessed 1 October 2019].

Hollander, M., Wolfe, D.A. 1999. Nonparametric Statistical Methods. 2nd Edition. New York, Wiley. 787 pp.

Huang, M.T. 2013. Assessing the status of forests interior and shrubland birds. - Connecticut Wildlife Magazine, 33(1), 4-5. 
Kelly, J.J., Latif, Q.S., Saab, V.A., Veblen, T.T. 2018. Spruce Beetle outbreaks guide American Three-toed Woodpecker Picoides dorsalis occupancy patterns in subalpine forests. - Ibis, 161(1), 172-183.

King, D.I., Chandler, R.B., Collins, J.M., Petersen, W.R., Lautzenheiser, T.E. 2009. Effects of width, edge and habitat on the abundance and nesting success of scrub-shrub birds in powerline corridors. - Biological Conservation, 142(11), 2672-2680.

King, D.I., Degraaf, R.M., Griffin, C.R. 2001. Productivity of early successional shrubland birds in clearcuts and groupcuts in an eastern deciduous forest. - Journal of Wildlife Management, 65(2), 345-350.

King, D.I., Schlossberg, S. 2014. Synthesis of the conservation value of the early-successional stage in forests of eastern North America. Forest Ecology and Management, 324, 186195. DOI:10.1016/j.foreco.2013.12.001

Krementz, D.G., Christie, J.S. 2000. Clearcut stand size and scrub-successional bird assemblage. The Auk, 117(4), 913-924.

Lebbin, D.J., Parr, M.J., Fenwick, G.H. 2010. The American Bird Conservancy Guide to Bird Conservation. Chicago, University of Chicago Press. 456 pp.

Liefert, J. 2008. Songbird banding in Naugatuck State Forest. - Connecticut Wildlife, 28(5), 4-5.

Mann, H.B., Whitney, D.R. 1947. On a test of whether one of two random variables is stochastically larger than the other. - The Annals of Mathematical Statistics, 18(1), 50-60.

Marshall, M.R., DeCecco, J.A., Williams, A.B., Gale, G.A., Cooper, R.J. 2003. Use of regenerating clearcuts by late-successional bird species and their young during the post-fledging period. - Forest Ecology and Management, 183(1-3), 127-135.

McKnight, T.L., Hess, D. 2008. Physical Geography: A Landscape Appreciation. 9th Edition. Boston, Prentice Hall. 720 pp.

NOAA. 1975. The Coastline of the United States. [WWW document]. - URL https://shoreline. noaa.gov/_pdf/Coastline_of_the_US_1975. pdf. [Accessed 22 August 2019].

Northeast Utilities. 2015. Northeast utilities specification for rights-of-way vegetation management. Hartford, Connecticut. [WWW document]. - URL https://www.eversource. com / content / docs / default-source / Tranmission/rights-of-way-guidelines.pdf. [Accessed 22 August 2019].
Rodewald, A.D. 2001. Managing for forest songbirds. [WWW document]. - URL http:/ / woodlandstewards.osu.edu/sites / woodlands/files / d6/files / pubfiles / Managing \% 20Forest \% 20Songbirds \% 20-\%20 Guide.pdf. [Accessed 9 June 2019].

Schlossberg, S., King D.I. 2007. Ecology and management of scrub-shrub birds in New England: A comprehensive review. - Report submitted to Natural Resources Conservation Service, Resource Inventory and Assessment Division. Beltsville, Maryland, USA. 122 pp.

Sibley, D.A. 2000. The Sibley Guide to Birds. 1st Edition. New York, Alfred A. Knopf. 544 pp.

Taylor, R.L., Maxwell, B.D., Boik, R.J. 2006. Indirect effects of herbicides on bird food resources and beneficial arthropods. - Agriculture, Ecosystems and Environment, 116(3-4), 157164.

Tefft, B.C. 2006. Managing shrublands and old fields. - Oehler, J.D., Covell, D.F. (eds.). Managing Grasslands, Shrublands, and Young Forest Habitats for Wildlife: A Guide for the Northeast. Massachusetts, Division of Fisheries \& Wildlife: The Northeast Upland Habitat Technical Committee, 1-7.

Terwilliger Consulting Inc. 2015. Threats to Connecticut's GCN species and their key habitats. - Connecticut Wildlife Action Plan $(6,21)$. Hartford, CT, The Connecticut Department of Energy and Environmental Protection Bureau of Natural Resources.

U.S. Census Bureau. 2019. QuickFacts: Connecticut. WWW document]. - URL www.census. gov/quickfacts/fact/table/CT/PST045218. [Accessed 23 May 2019].

Vitz, A.C., Rodewald, A.D. 2006. Can regenerating clearcuts benefit mature-forest songbirds? An examination of post-breeding ecology. Biological Conservation, 127(4), 477-486.

Wenny, D.G., DeVault, T.L., Johnson, M.D., Kelly, D., Sekercioglu, C.H., Tomback, D.F., Whelan, C.J. 2011. The need to quantify ecosystem services provided by birds. - The Auk, 128(1), 1-14. DOI:10.1525/auk.2011.10248.

Yoon, C.K. 1994. More than decoration, songbirds are essential to forests' health: As birds like scarlet tanagers decline, so could trees on their migration path. - New York Times, 4. 